\title{
Brugerinddragelse i arkitektoniske og organisatoriske designprocesser
}

\author{
Marianne Stang Våland \& Susse Georg
}

Kan rum, rummets design og de materielle artefakter, der anvendes til at visualisere et arbejdsrum, bruges som organisationsudviklingsværktøj? Denne artikel belyser nogle af de muligheder og udfordringer, der opstår, når ledelsen søger at iværksætte et organisationsudviklingsprojekt i forbindelse med et bygge- og indretningsprojekt; når ledelsen igangsætter 'en dobbelt designproces', hvor hverken det organisatoriske design tages som præmis for arbejdsrummets design, eller omvendt.

"Jeg tror ikke, at der er ret mange, der endnu har prøvet på deres krop, at man kan lave en dobbelt designproces, og at en af opgaverne $i$ tilretteloeggelsen af det forandringsforløb er at lave en eller anden form for vekselvirkning eller synergi mellem dem [arbejdsrummets og organisationens design]. [...] Jeg er blevet opmoerksom på, hvor vitalt det $i$ virkeligheden er ikke at fastlåse eksempelvis den organisatoriske udvikling som en given forudsaetning og så snakke rum, men blive ved med at gøre det, så der er en vekselvirkning [...]. Det klassiske vil jo voere at skille dem ad, og hvis de kommer til at have en eller anden form for indbyrdes sammenhoeng, så er det mere held end forstand. Det, tror jeg, er fordi, man ikke endnu er kommet til at have erkendt det fysiske rums betydning som ledelsesvoerktøj" (Interview med dansk kommunaldirektør 2007).

C itatet ovenfor beskriver en kommunaldirektørs tilgang til et stort organisationsforandringsprojekt. Det skal foregå igennem det, han kalder en 'dobbelt designproces', hvor hverken det organisatoriske design tages som præmis for arbejdsrum- mets design, eller omvendt. Med denne tilgang ville kommunen kunne opnå en bedre sammenhæng mellem de to. Samtidig antyder kommunaldirektøren, at mange ledere underkender rummets betydning. Selvom der nok er bred enighed om, at rum spiller en væsentlig rolle både i livet og i arbejdslivet (Chanlat 2006), er det vanskeligt at sige noget entydigt om, hvordan rummets indretning påvirker medarbejdernes interaktion og deres brug af rummet (Bjerrum m.fl. 2007) ${ }^{1}$.

Den tilgang, som kommunaldirektøren foreslår, synes at være i tråd med den tiltagende debat om designtænkning i organisationsudvikling (Bate 2007; Bevan m.fl. 2007) og ledelse (Boland \& Collopy 2004; Martin 2007). Idéen er, at ledere kan lære af den måde, designere arbejder på. Ikke alene kan designtænkning bruges til at berige ledelsesarbejdet. Det kan også være et strategisk værktøj til at forbedre organisationers innovationsevne og dermed et middel til at fremme udviklingen af en mere kreativ og innovativ økonomi. Det er således ikke småting, tilgangen synes at muliggøre, og dette kan være en af grundene til dens 
popularitet i det seneste årti (JohanssonSkjöldberg m.fl. 2013).

Men trods den voksende interesse er der ikke mange forskningsmæssige bud på, hvordan man konkret kan arbejde med en tilgang, som bygger på designtænkning i organisationer. I denne artikel diskuterer vi et bud på, hvordan man kan konkretisere idéen om 'ledelse som designarbejde', populariseret med udgivelsen af bogen Managing as Designing (Boland \& Collopy 2004). Vi gør det i kontekst af den udviklingsopgave, som ovennævnte kommunaldirektør stod overfor, da han skulle stå for fusioneringen af to kommuner som følge af Strukturreformen i 2007. I fokus for opgaveløsningen stod den idé, han præsenterer i citatet ovenfor, altså samspillet mellem det rumlige og det organisatoriske design. Den måde, relationen mellem de to designprocesser blev skabt og opretholdt på, var igennem en høj grad af organiseret brugerinddragelse. I artiklen undersøger vi, hvad det vil sige at åbne 'den dobbelte designproces' op for andre end lederen og dennes rådgivere. Inspireret af indsigter fra aktør-netværkteori er vores teoretiske argument, at design af organisatoriske forandringer snarere skal ses som en socio-materiel effekt end som resultat af en ledelsesbeslutning, der er den mere udbredte forestilling.

Artiklen bygger på en etnografisk undersøgelse af brugerinddragelse i designet af et dansk rådhus (Stang Våland 2010), der skulle rumme den nye kommune. Undersøgelsens fokus var involveringen af en stor gruppe af bygningens slutbrugere ${ }^{2}$ i den designproces, som drejede sig om designet af rådhusets fysiske indretning. Både hvad angår omfang og indhold, gik brugerinddragelsen langt udover den kontakt, man normalt ser mellem klient, arkitekt og andre rådgivere i traditionelle byggeprojekter. I analysen viser vi, hvordan de forskellige typer af materielle artefakter, som blev an- vendt i processen, fik betydning for medarbejdernes oplevelser af den kommende arbejdsplads' rumlige organisering. Materialiteterne udgjorde på den ene side en løftestang for deltagerne til at forstå mere om både egne og andres arbejdsopgaver - $\mathrm{i}$ den enkelte afdeling og på tværs af organisationen. På den anden side bragte interaktionen med materialiteterne også en udfordring med sig for lederen: Når deltagernes samtaler om forholdet mellem arbejdet og arbejdsrummet i bogstavelig forstand blev fysisk, skabte det forventninger og ejerskab, som introducerede nye ledelsesmæssige udfordringer. Artiklens bidrag er, at udfolde den teoretiske idé om 'ledelse som designarbejde' ved at diskutere denne tilgang gennem anvendelsen af organiseret brugerinddragelse. For selvom der skrives meget om den rolle, design og designtænkning kan spille i organisatorisk arbejde, er der ikke meget i denne litteratur, som diskuterer de ledelsesmæssige dilemmaer som designtilgangen involverer.

I det følgende introducerer vi den litteratur, som ligger til grund for vores ærinde. Derefter retter vi blikket mod det etnografiske studium, som udgør artiklens empiriske udgangspunkt: Vi beskriver først studiets metodiske tilgang og præsenterer casen, hvorefter vi illustrerer, hvordan den dobbelte designproces udspillede sig. I diskussionen fokuserer vi på nogle af de muligheder og dilemmaer, den dobbelte designproces kan rumme for lederen.

\section{Organisationsdesign som socio- materiel praksis}

Designtænkning er i løbet af det sidste årti blevet en vigtig inspirationskilde inden for fx ledelse (Boland \& Collopy 2004; Yoo m.fl. 2006), organisationsudvikling (Bate 2007), forandringsledelse (Bevan m.fl. 2007; Peltonen 2011) og organisationsteorien mere 
generelt (Romme 2003; Jelinek m.fl. 2008; Greenwood \& Miller 2010). I det følgende tager vi udgangspunkt i Boland og Collopys arbejder om 'managing as designing' (2004; 2008), da de netop har ledelse som deres fokus.

Ifølge Boland og Collopy (2004) er der, groft sagt, to tilgange til, hvordan man ledelsesmæssigt kan agere. Den ene er den rationalistiske 'beslutningstilgang', der baseres på forestillingen om, at organisationsdesign primært er et spørgsmål om at vælge mellem kendte alternativer, beslutte hvilket alternativ, det skal være og dernæst sikre, at dette implementeres. Denne tilgang er imidlertid mindre velegnet i situationer, der kendetegnes af usikkerhed, og hvor man ikke ved, hvad der vil være den bedste, endsige 'optimale' løsning. Af samme grund argumenterer Boland og Collopy for, at mange organisationer ville være bedre stillet, hvis ledelsen anlagde en anden, mere åben procesorienteret tilgang. Det er det, de kalder en 'designtilgang'. Denne tilgang bygger på en forestilling om, at der i ethvert projekt er mulighed for at skabe noget markant nyt. Selvom udgangspunktet tages i det eksisterende - i folks praksisser, forventninger, eksisterende politikker, mv. - er en grundlæggende præmis for designtilgangen, at det eksisterende kan være anderledes, og at det kan ændres til det bedre (Boland m.fl. 2008, 13). Ved at stille spørgsmålstegn ved det eksisterende og facilitere processer, der gør det muligt for medarbejdere at se deres arbejdspraksis i et nyt lys, får ledelsen mulighed for at re-designe organisationen. Det er heri, designtilgangens innovative kraft ligger (Boland m.fl. 2008). I situationer, hvor ledelsesopgaven er kompleks og præges af mange forskelligartede udfordringer, drejer ledelse sig derfor mere om at udvikle forskellige idéer til handling end at træffe valget mellem kendte handlingsstrategier. Det er dog ikke ensbetydende med, at der ikke vil være mange situationer i et projekt, hvor en beslutningstilgang vil være påkrævet (Boland \& Collopy 2004).

Når designtilgangen er interessant i forhold til håndteringen af organisationsforandringer, er det, fordi den kombinerer det at designe og det at organisere. Ved at udfordre det eksisterende igennem udvikling af nye designforslag bliver det muligt at udfolde og eksperimentere med både designet og organisationen, så ledelsen kan afsøge alternative forslag til, hvordan en given forandringsproces skal håndteres. Ifølge Weick (2004) giver tilgangen mulighed for at medarbejdere kan lufte synspunkter og bekymringer over situationen, samtidig med at deres indbyrdes interaktioner kan bidrage til udviklingen af nye løsningsforslag. Her er fokus ikke på designintentionen og idéen om en endelig løsning (et design), men på de mange udvekslinger, som designprocessen omfatter, og alt det, som herigennem produceres og etableres. Det er faciliteringen af denne myriade af udvekslinger, som står i centrum for designtilgangen - hvor resultatet af alle de mange alternative idéer og løsningsforslag til sidst samles i det, han kalder 'bricolage' (Weick 2001; 2004).

Med henvisning til, hvordan arkitekten Frank O. Gehry arbejder, fremhæver Boland m.fl. (2008) et andet vigtigt aspekt ved designtilgangen, og det er brugen af mange forskellige former for visuelle repræsentationer af det, der skal designes. Tegninger, fotos, 3D-computermodeller mv. bruges til at vise og afprøve ideer og dermed fremprovokere reaktioner hos andre, samtidig med at de også kan bruges til at inddrage og engagere flere i designopgaven. Den rolle, som sådanne artefakter eller designobjekter kan tænkes at have, er begrebsliggjort på flere måder. Den nok mest anvendte konceptualisering er Star og Griesemers 'grænseobjekter' (1989). Det er objekter, som muliggør samarbejde på tværs af forskellige 
discipliner/faggrupper ved at være tilpas plastiske fortolkningsmæssigt, til at de kan anvendes af forskellige faggrupper, samtidig med at de har en vis stabilitet på tværs af anvendelsesområderne. Hertil kommer idéen om epistemiske objekter og tekniske objekter (Ewenstein \& Whyte 2007; 2009). Førstnævnte er mere abstrakte eller åbne, og deres egenskaber 'trigger' brugerens nysgerrighed og genererer spørgsmål, mens sidstnævnte nærmest er det modsatte - de er uproblematiske, stabile genstande/artefakter, som tages for givet. Ifølge Ewenstein \& Whyte $(2009,10)$ er et objekts rolle i en designproces ikke entydig. Objektet kan på én og samme tid være både et grænseobjekt og et teknisk objekt eller et grænseobjekt og et epistemisk objekt. I forlængelse heraf vil den betydning, som artefakter måtte have, afhænge af hvad og hvem, der er involveret i designprocesserne.

Set ud fra et aktør-netværksperspektiv er artefakterne og de repræsentationer, der fremstilles af dem, non-humane aktører. Aktør-netværksteori er tidligere blevet introduceret i tidsskriftet (Buch 2007; Abildgaard m.fl. 2012), hvorfor vores redegørelse vil være mere kortfattet og kun fokusere på de dele af begrebsapparatet, der informerer analysen. Teorien baserer sig på en relationel ontologi (Latour 2005), hvor både det sociale (humane) og det materielle (non-humane) har status af aktører med mulighed for at handle. Således betragtes både viden, videnskab, teknologier, organisationer og institutioner som et produkt eller en effekt af et heterogent netværk bestående både af mennesker og materialer (Law 1992).

I vores case betyder det, at de mange materielle artefakter, som blev anvendt i brugerinddragelsen, alle var aktører i netværk, der blev dannet i løbet af processen. Disse er kun midlertidigt stabile, da der hele tiden kan opstå nye relationer og nye netværk igennem det, Callon (1986) har betegnet som translations- eller oversættelsesprocesser. ${ }^{3}$ I forlængelse heraf kan eksempelvis et færdigt design betragtes som et ordnet netværk, hvor al modstand - menneskelig såvel som materiel ${ }^{4}$ - er (midlertidigt) overvundet, indtil der er nogle eller noget i netværket, der begynder at problematisere designet, eller på anden vis får det til at falde fra hinanden. Designet kan fx udfordres af økonomien, tidskrav, medarbejdernes ønsker og af materialerne anvendt i bygge- og indretningsprocesserne, hvorved den 'orden', som det er udtryk for, undermineres helt eller delvist. I forhold til vores case er hensigten således at undersøge, hvordan de materielle artefakter, der anvendes i brugerinddragelsen til at repræsentere det nye rådhus, virker: Hvad de bidrager med i denne udviklingsproces.

De artefakter, der mobiliseres i casen, er det, man i aktørnetværks-termer kalder 'intermediaries' og 'mediators' (Latour 2005, 39). Førstnævnte er blot ting, der passerer mellem folk og transporterer eller formidler information fra en situation til en anden, mens 'mediators' kan transformere, oversætte, forandre eller forvrænge den mening, som de burde formidle. Hermed udfordres den sædvanlige forestilling om artefakter som værende 'intermediaries' ved i stedet at fastholde, at artefakter kan være aktivt involverede i skabelsen af det, de siges at repræsentere. I nogle tilfælde kan et artefakt optræde som det ene og i andre tilfælde som det andet. Dette kan ikke specificeres forlods, men kun afsløres i de konkrete processer, hvori artefakterne tages i brug og udfolder sig. I forhold til design- (og andre) processer kan de være vigtige værktøjer, eller 'devices' (Callon 1986), for oversættelsesprocesserne.

På denne baggrund analyseres 'den dobbelte designproces' som en kæde af oversættelsesprocesser. Det tidspunkt i projektet, hvor vi kommer ind, er præget af betydelig 
usikkerhed, idet hverken det organisatoriske eller det indretningsmæssige design var på plads. De var således ikke givne størrelser, men noget der skulle udvikles, bl.a. igennem at inddrage de ansatte i designprocessen. Af omfangsmæssige grunde fokuserer vi kun på en begrænset del af designprocessen, men mere herom i de kommende afsnit.

\section{Metodisk tilgang}

Artiklens empiriske materiale er hentet fra den ene forfatters etnografiske studium af organiseret brugerinddragelse i arkitektoniske designprocesser i forbindelse med kontorbyggeri (Stang Våland 2010). Materialet blev produceret over en treårig periode (2005-2008) med udgangspunkt i tre primære forskningsmetoder: deltagerobservation, semistrukturerede interviews og dokumentanalyse. Studiet omfattede to cases, hvor rådhusprojektet er det ene.

Casens datamateriale omfatter bl.a. 21 semistrukturerede interviews med projektets parter, foretaget i perioden 2007-2008. Informanterne repræsenterede bygherreorganisationen (kommunaldirektør, afdelingsledere, medarbejdere og projektledere), arkitektfirmaet, som havde vundet arkitektkonkurrencen (arkitekter og ansvarshavende partner), samt det arkitektfirma, som stod for brugerinddragelsen (direktør og medarbejdere - alle uddannede arkitekter). Alle interviews havde en varighed på en til halvanden time, og alle blev optaget og efterfølgende transskriberet.

Forud for gennemførelsen af de fleste interviews gennemførte den ene forfatter et omfattende feltarbejde i form af deltagerobservation. Dette involverede seks heldagsworkshops med deltagelse af ca. 50 af kommunens medarbejdere (for hvem rådhuset ville blive deres daglige arbejdsplads); to tretimers stormøder, hvor alle medarbejderne var inviteret; fire møder mellem bygherrens repræsentanter og det designteam, som havde vundet arkitektkonkurrencen; tre udviklingsmøder mellem kommunens topledelse og det firma, som var ansvarlig for brugerinddragelsen. I tillæg bestod feltarbejdet af et tre måneders fuldtidsophold hos det arkitektfirma, som var ansvarlig for brugerinddragelsen. Dette ophold omfattede en lang række uformelle diskussioner i forbindelse med planlægningen af de brugerinddragelsesaktiviteter, som blev anvendt i rådhusprojektet. Datamaterialet involverede desuden en stor mængde dokumenter vedrørende etableringen af det nye rådhus og de mange aktiviteter, projektet bragte med sig: projektbeskrivelser, referater og notater, materialer som beskriver brugerinddragelsen, skitser og diagrammer af bygningens design både udvendigt og indvendigt mv. Dokumenterne gav et værdifuldt overblik over de mange parter, projektet involverede, og nogle af dem dannede desuden baggrund for interviews og feltarbejde.

Casen fokuserer på tre workshops, der drejede sig om relationen mellem arbejdspraksis og arbejdsrum, og som involverede brugen af materielle artefakter såsom tegninger, fotografier, diagrammer, spilleplader og andre objekter, der blev brugt til at repræsentere de mange funktioner og samarbejdsforhold, det nye hus forventedes at rumme. Det er netop anvendelsen af disse artefakter, som er i fokus for vores analyse. Workshoppene adskiller sig ved, at workshop 1 og 2 var organiseret med udgangspunkt i spilleplader og spillebrikker og således $i$ et $2 \mathrm{D}$-format, mens den tredje workshop foregik i 3D, hvor der blev arbejdet med arbejdsrummet i 1:1-størrelse. Her repræsenterede en række skumbrikker arbejdsrummets forskellige arbejdsgenstande: skriveborde, arkiv mv. Derudover er de tre workshops valgt, fordi deltagerne arbejdede med bygningen og arbejdsrummet ud fra 
forskellige synsvinkler. I workshop 1 arbejdede deltagerne som udgangspunkt med organiseringen af hele huset, mens omdrejningspunktet for workshop 2 var arbejdsprocesser i lokalområdet. I workshop 3 fik deltagerne mulighed for at afprøve forskellige måder at organisere deres arbejdsrum på - i fuld størrelse.

I forbindelse med dataanalysen blev feltnoter, transskriberede interviews ${ }^{5}$ og dokumenter først gennemgået og tematiseret i en række generelle kategorier (Braun og Clarke 2006), såsom: brugerinddragelse (intentioner, bekymringer, erfaringer), typer af brugerinddragelsesaktiviteter (planlægning og udvikling af de forskellige aktiviteter), særlige betingelser, som definerede designet (fx åbne kontorlandskaber), samt bygningsarkitekternes oplevelse af at deltage i en proces, hvor brugerinddragelse blev gjort til et centralt element. Disse kategorier blev derefter gennemgået igen, denne gang med fokus på erfaringer med brugerinddragelsens workshops. Dette resulterede i nye temaer om: åbne kontorlandskaber (forestillinger og holdninger), forholdet mellem arbejdsprocesserne og arbejdsrummet, deltagernes erfaringer med de konkrete workshops samt idéen med den dobbelte designproces. Et af aspekterne, som gik på tværs af disse temaer, var den rolle, som materialiteter spillede i brugerinddragelsens aktiviteter, hvorfor dette er gjort til et af analysens omdrejningspunkter.

\section{Artiklens empiriske kontekst}

Som følge af Strukturreformens kommunesammenlægning skulle arbejdet $\mathrm{i}$ de to gamle kommuner reorganiseres. Men forud for denne beslutning havde den ene kommune forhandlet på plads, at der skulle opføres et nyt rådhus i byen. Da strukturreformen blev en realitet, så kommunaldirektøren etableringen af det nye rådhus som en mulighed for at igangsætte de organisatoriske ændringer, som sammenlægningen krævede. Det er denne kobling mellem udviklingen af et nyt organisatorisk design og indretningen af rådhuset, den rumlige designproces, kommunaldirektøren kalder 'den dobbelte designproces'. Samtidig var han inspireret af den aktuelle debat om videndeling og tværfaglighed som kilder til fornyelse og innovation (Indenrigs- og Sundhedsministeriet 2005), herunder indførelsen af 'new office' i åbne kontormiljøer. Sidstnævnte blev en økonomisk og arkitektonisk præmis for projektet. Organiseret brugerinddragelse blev gjort til den centrale løftestang i bestræbelserne på at koble de to designprocesser. Konkret omfattede brugerinddragelsen en dialogrunde, hvor kommunaldirektøren besøgte alle afdelinger; en spørgeskemaundersøgelse til kortlægning af medarbejdernes anvendelse af rummet (i de gamle bygninger); en række workshops med deltagelse på tværs af organisationen; afdelingsvise workshops; to stormøder kort før indflytning, hvor arkitekterne svarede på spørgsmål fra brugerne om forholdene i bygningen; samt en fest, hvor medarbejderne blev inviteret på rundvisning i rådhuset, nogle måneder inden huset var indflytningsklart. Dialogrunden mellem direktør og afdelinger samt de første tre workshops på tværs af organisationen fandt sted inden arkitektkonkurrencen, mens de øvrige aktiviteter foregik i den periode, hvor designet af huset blev udviklet, samt op til selve indflytningen. Kommunaldirektøren og områdedirektørerne deltog selv i alle de tværgående workshops, men ikke i de afdelingsvise workshops.

Forholdet mellem arbejdsprocesser og arbejdsrum var omdrejningspunkt for samtlige aktiviteter. Man drøftede, så at sige, arbejdet gennem diskussioner af, hvordan de fysiske rammer skulle udformes. I nedenstående citat forklarer kommunaldirek- 
tøren, hvordan han synes, arbejdsprocesser og arbejdsrum hænger sammen:

"Mange opfatter det at flytte fysisk som noget, der omfatter de faktiske fysiske rammer, de sidder i og den adresse, deres arbejde befinder sig på. Men at det viser sig, at det omfatter selve arbejdets indhold - sådan er vi ikke opdraget til at toenke. Det at indholdet bevidst og ubevidst spiller sammen med de rammer, det bliver udfoldet $i$, og det at afstande, tilgaengelighed etc. påvirker arbejdets egentlig indhold - det skaber en oendret arbejdsopfattelse."

Citatet udtrykker flere ting: at arbejdspladsens indretning spiller en aktiv rolle $i$, hvordan arbejdet tilrettelægges og opfattes, og at disse to forhold gensidigt påvirker hinanden. Det er den dobbelte designproces - en proces, som gav anledning til at diskutere de kommende organisationsændringer sammen med dem, ændringerne skulle omfatte. På den måde så han etableringen af rådhuset som:

"[...] en gave til fusionen. Der kan alle indtage den nye organisation mere eller mindre fri af fortiden og vi/de-skel og alt muligt andet. [...] Det, vi har fokus på, er jo det at binde ting sammen på tvaers. At opnå en raekke sammenhoenge $i$ form af faglighed, der bliver til tvaerfaglighed. At opnå en helhedstoenkning $i$ forhold til de meget stoerke faggrupper, vi har så mange af. Og der bliver man nødt til at kikke på, hvordan det fysiske rum understøtter eller hoemmer de samarbejdsmodeller."

Den dobbelte designproces repræsenterede en lejlighed for både ledelsen og medarbejderne til at italesætte og drøfte de mange organisatoriske udfordringer, som knyttede sig til fusionen. I citatet markerer kommunaldirektøren at større tværfaglighed i ar- bejdet vil være en ændring i forhold til den måde, de to administrationer hidtil havde arbejdet på. Denne tværfaglighed skulle blandt andet understøttes gennem etableringen af åbne kontorlandskaber for både lederne og medarbejderne i kommunen. Selv om denne beslutning lå fast, var der mange andre forhold, som var til diskussion i forbindelse med rådhusets indretning. Brugerinddragelsen var kommunaldirektørens redskab til at organisere 'samtalerne' herom: mellem kommunens medarbejdere, mellem medarbejdere og ledelse, mellem organisationen og de arkitekter, som skulle designe bygningen, og endelig mellem medarbejderne og de mange materielle artefakter, som var en del af brugerinddragelsesaktiviteterne.

Mange af disse var baseret på en udstrakt brug af visualiseringer - tegninger, diagrammer, fotografier, spilleplader med dertilhørende spillebrikker og andre materielle artefakter, der kunne bruges til at repræsentere bygningens fremtidige 'layout' og de kommende kontorarbejdspladser. Som repræsentationer af det fremtidige arbejdsrum stod artefakterne centralt i iscenesættelsen af disse aktiviteter.

Trods en stigende interesse for både arbejdsrum, arkitektur og materialitet i organisationsteorien er der stadig kun få detaljerede, empiriske undersøgelser af samspillet mellem de rumlige og materielle forhold og organisationsudviklingen. I det følgende illustrerer vi, hvordan omgangen med rum og materialiteter fik betydning for de medarbejdere, som deltog i designprocessen. Deltagerne fik både lejlighed til at bidrage til udviklingen af arbejdsprocesserne og til at drøfte implikationerne af $\mathrm{fx}$ at skulle arbejde i åbne kontorlandskab. Men mødet med materialiteterne gav ikke kun anledning til at overveje arbejdets indhold. Det skabte også et stærkt ejerskab til de designidéer, som blev udviklet. På den ene side 
gav materialiteterne altså deltagerne en konkret, fysisk oplevelse af den ændring, som lå forude, hvorfor det måske blev lettere for dem at acceptere de nye forhold. På den anden side var de materielle repræsentationer med til at skabe håndfaste forventninger hos brugerne. Resultatet var, at mange af deltagere blev skuffede, da deres input ikke var afspejlet i det endelige design af arbejdsrummet. I diskussionen vender vi tilbage til den betydning, materialitet kan få i mødet med det sociale, og ser på, hvilke ledelsesmæssige udfordringer denne form for brugerinddragelse kan indebære.

\section{Inddragelse gennem materialiteter og samtaler om rum}

Arbejdsrummet er som regel noget, man tager for givet, lige indtil det tidspunkt, hvor det ændres. Sådan var det også i rådhusprojektet: Fusionen mellem de to kommuner indebar ikke kun at medarbejderne skulle flytte fra en adresse til en anden, at de fik nye kollegaer, og at en række arbejdsprocesser skulle tilpasses og ændres. I tillæg hertil kom, som sagt, at ledelsen havde besluttet, at arbejdspladserne skulle organiseres som åbne kontorlandskaber. Det var en beslutning, som blev mødt med stor skepsis blandt kommunens medarbejdere. I det følgende citat fortæller medarbejder 1, som arbejder med familier med særlige behov, hvorfor hun bekymrer sig for de åbne landskaber i forhold til kommunikationen med borgerne:

"Jeg skal slet ikke loegge skjul på, at vi, medarbejderne, har voeret rigtig, rigtig bekymrede, fordi vi synes, at vores arbejde er rigtig velegnet til små kontorer, hvor vi kan sidde med brugerne og drøfte ting osv., have vores arbejde i fred og tale i telefon osv."

Denne medarbejders - og mange af hendes kollegaers - skepsis over for de åbne kontorer fortsatte sådan set igennem hele projektet, og ligesom hende ville mange formentlig stadig have foretrukket cellekontorer efter indflytningen, hvis de havde kunnet vælge. Men vores undersøgelse tyder også på, at deres deltagelse i udviklingen af arbejdsrummets design var med til at udfordre deres forestillinger om og holdninger til, hvordan arbejdet i rådhuset kunne foregå. Dette illustreres i det følgende, hvor vi fokuserer på tre workshops fra brugerinddragelsen, som var organiseret gennem brugen af forskellige typer af materielle artefakter.

\section{Tre typer af workshops}

Den ene workshop handlede om, hvordan de forskellige afdelinger i kommunens administration skulle placeres i forhold til hinanden. Her arbejdede deltagerne i grupper på tværs af organisationen og diskuterede, hvordan samarbejdet kunne foregå i det nye hus, hvilke funktioner/services, som skulle ligge i nærheden af hinanden, og hvorfor dette var vigtigt. I den anden workshop diskuterede medarbejdere fra den samme afdeling, hvordan arbejdet kunne organiseres i et åbent kontorlandskab. I begge disse workshops var de centrale øvelser organiseret som brætspil, hvor spillet gik ud på at deltagerne i mindre grupper skulle indrette bygningen og kontorerne. I den ene workshop repræsenterede spillepladen hele bygningen (workshop 1), mens deltagerne i den anden workshop blev præsenteret for et par generelle eksempler på, hvordan en afdeling kunne indrettes som et åbent kontor (workshop 2). Disse forslag til indretning var udarbejdet af de arkitekter, som organiserede brugerinddragelsen, og blev som sådan taget for gode varer. Ud fra disse forslag diskuterede workshopdeltagerne indretningens betydning for deres arbejde uden at udvikle alternative forslag til kontorets indretning. Hvert 'spil' omfattede spillebrikker, der angav forskellige funktio- 
ner og personer, og hvis placering på pladen udgjorde diskussionernes udgangspunkt.

Workshoppene afsluttedes ved, at grupperne præsenterede deres samlede input i plenum. Til flere workshops kom der spørgsmål fra deltagerne om, hvordan det producerede materiale skulle anvendes. Svaret var, at materialet ville blive bearbejdet af det arkitektfirma, som organiserede brugerinddragelsen, og derefter drøftet med ledelsen. Det blev desuden understreget, at selvom de mange input fra brugerne ikke alle sammen kunne genfindes i den valgte løsning, var det samlede materialet vigtigt for arkitekternes arbejde med at udvikle forskellige løsningsforslag. Med udgangspunkt i deltagernes input udarbejdede arkitekterne en række såkaldte 'scenarier' for husets rumlige organisering til ledelsen herunder et scenarie, de som rådgivere ville anbefale. Scenarierne blev drøftet mellem ledelse og arkitekter, hvorefter ledelsen traf beslutninger om husets indretning.

\section{Samarbejde, læring og luft for bekymringer}

De to første workshops efterlod mange deltagere interesserede i selve indholdet: designet af deres fremtidige arbejdsrum og tilrettelæggelsen af arbejdsprocesserne. Men vores data viser, at der stadig var mange ubesvarede spørgsmål og bekymringer om, hvilke ændringer det nye hus ville betyde for deres arbejde. Medarbejder 2, som er HR-konsulent fortæller:

"Man har kunnet moerke på de workshops [med udgangspunkt i spillepladerne], at folk har gået til den og virkelig snakket frem og tilbage, og man har voeret lidt uenig en gang imellem, fordi sådan er det ikke hos os, og sådan er det hos dem osv. Så på den måde har man så også loert hinandens områder at kende. [...] Men så sidder man bare og toenker: 'Hvor langt er der så fra det skrivebord og dér over til', fordi det var alligevel rigtig svoert at forestille sig på de her spilleplader. [...] Man snakker nu om at finde en hal, hvor man kan lave sådan en [workshop], hvor man kan stille sin afdeling op, så man kan forestille sig: 'Jamen, der er faktisk højt til loftet, der er langt til det noeste skrivebord'. Så det der med at vi skal sidde 15 i et rum, det er måske slet ikke så slemt."

Som medarbejderen indikerer, gav diskussionerne anledning til at lære nye ting om arbejdet i de forskellige afdelinger. Men det var begrænset, hvor meget disse visualiseringer fortalte om de nye kontorlandskabers faktiske rumlighed. I citatet efterlyser hun den workshop, som netop var under planlægning, da interviewet fandt sted, og som er den næste workshop, vi beskriver her i artiklen. Denne workshop havde en anden karakter end de to første. Her var formålet at bygge en såkaldt 'mockup' i størrelse 1:1 af de enkelte afdelingers arbejdsrum, så medarbejderne kunne opleve/eksperimentere med pladsanvendelsen. Øvelsen foregik i en hal i udkanten af byen, hvor konturen af den enkelte afdeling var kridtet op med stiplede linjer på gulvet, og skumbrikker i forskellige størrelser repræsenterede arbejdsrummets møbler: skriveborde, arkiv, og andet inventar (se foto A på næste side).

Inspireret af filminstruktøren Lars von Triers uortodokse scenografi i filmen Dogville (2003) var idéen at give deltagerne en konkret, fysisk oplevelse af det kommende arbejdsrums størrelse og form.

\section{Når brugerne bliver designere}

Workshoppen omfattede to øvelser. Den første øvelse havde titlen "En dag på arbejde", hvor deltagerne skulle placere sig selv i lokalet i forhold til varetagelsen af de forskellige administrative arbejdsopgaver, som de normalt beskæftigede sig med i afdelingen. Medarbejder 1 fortæller: 
Foto A. Medarbejderne designer deres eget arbejdsrum.

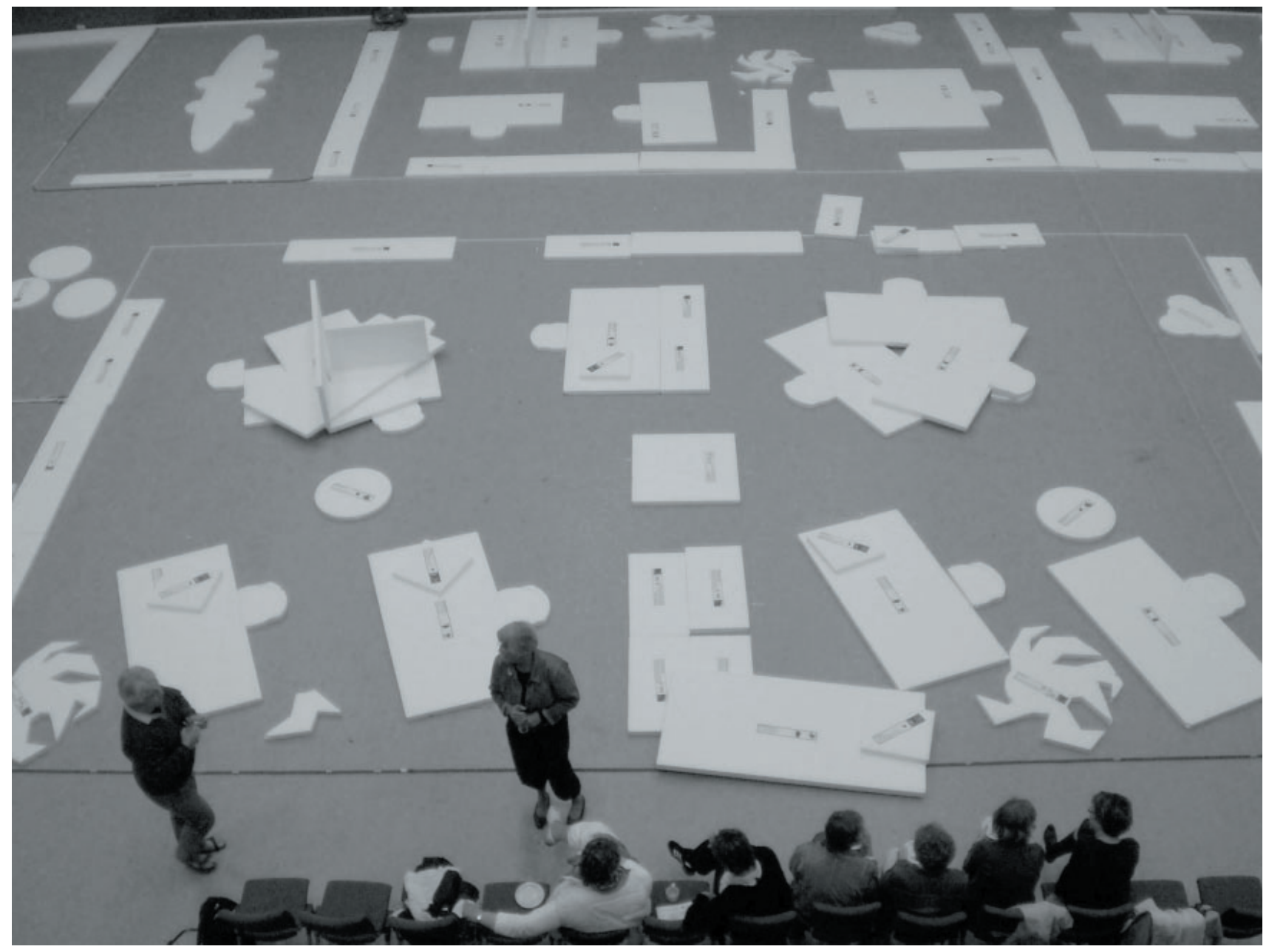

"[Øvelsen] bestod i, at vi fik nogle kort, og der stod: 'Du holder møde med - en eller anden'. Eller: 'Du taler i telefon'. Eller: 'Du laver administrativt arbejde'. Man fik en arbejdsfunktion, og ud fra den skulle man så [...] placere sig et sted. [F]olk skulle have oplevelsen af, at jeg kan bevoege mig rundt. Jeg er ikke bundet til ét sted. Og de skulle også have oplevelsen af, at når vi nu har så forskelligartede opgaver, så betyder det, at der står ledige skriveborde hele tiden."

I citatet beskriver medarbejderen dels deltagernes kropslige oplevelse af arbejdsrummets størrelse og erfaring med, hvordan rummet blev anvendt - eller netop ikke anvendt. Når man er medarbejder med eget kontor, tænker man som regel ikke over den ressource, som det repræsenterer. Men når plads og rum kommer i centrum for en drøftelse, bliver rummet gjort til en ressource. I øvelsen blev rummets faktiske anvendelse gjort tydelig i den forstand, at det blev fysisk - hvorfor det også blev tydeligt, hvordan rummet ikke var aktivt. Men ved at beskrive øvelsen i termer af, hvad hun anser som dens formål, afslører hun også en forestilling om, at øvelsens resultat eller svar var givet på forhånd. På denne måde indikeres det, at brugerinddragelsen også kan ses som en legitimering af allerede trufne beslutninger.

I workshoppens anden øvelse blev deltagerne bedt om at udvikle et udkast til en dis- 
position for afdelingens eget arbejdsrum. I nedenstående citat fortæller medarbejder 1 videre om hendes og kollegernes refleksioner over og omgang med de skumbrikker, som blev benyttet som repræsentationer for arbejdsrummets centrale arbejdsgenstande:

"[O]g så kunne man flytte rundt på de her hvide brikker - flytte ud og flytte ind, og hvordan vil man så arrangere sin afdeling? Hvad lagde man vaegt på? Hvordan ville man gerne have det? Skulle det vaere fire borde ved siden af hinanden eller tre i en rundkreds? Skulle de stå forskudt? Hvor meget arkivskab og sådan noget skulle der voere? [...] Folk var da rimelig optaget af det."

Artefakterne i workshoppen bragte, som Latour (1987) ville sige, deltagerne sammen, indrullerede dem i øvelser om arbejdsrummets indretning, og gjorde det muligt for dem at drøfte arbejdet i det fremtidige arbejdsrum. Gennem øvelsernes fysiske ramme fik de i bogstavelig forstand håndgribelige muligheder for at eksperimentere med indretningen og herigennem forstå, hvordan det åbne kontorlandskab kunne tænkes at indvirke på deres arbejde. Medarbejder 3, der arbejder med 'facility management', forklarer, hvordan projektets abstrakte visioner om 'new ways of working' fik liv gennem medarbejdernes deltagelse, idet øvelsernes fysiske udformning gav mulighed for at:

"...komme toettere på en realistisk forestilling om, hvad det her indeboerer. For hvis [medarbejderne] kun loeser på et stykke papir om 'aktivitetsbaseret arbejdsmiljø' - det er jo noget floskelsprog, der er udformet lidt reklameagtigt. Det er sødsuppe alt sammen - der er ikke noget kritisk! Så jeg tror, at de netop havde brug for at holde workshops og komme i gang med at lave en praktisk indretning af deres område - og så forholde sig til det. Der tror jeg, at de workshops [i 1:1-for- mat] har voeret gode, for det er så toet på, som man kan komme."

Den fysiske organisering af brugerinddragelsen i denne workshop skabte altså ikke kun mulighed for at forstå mere om de overordnede idéer, projektet var bygget på. Den gjorde det også muligt at undersøge, hvad sådan et 'aktivitetsbaseret arbejdsmiljø' kunne betyde i praksis. Processen afdækkede desuden ting om den daglige praksis, som ikke kun var nyttige informationer for de involverede arkitekter. For som medarbejder 3 påpeger, kom der også ting frem, som var nye for medarbejderne selv:

"Og så har vi fået en masse viden, som vi ellers ikke ville have fået, og som jeg heller ikke er sikker på, at medarbejdergrupperne selv har voeret bevidste om - det [arbejdsprocesser] er sådan en skjult ting [...]"

Spillepladerne var 'intermediaries' i processen: redskaber gennem hvilke deltagerne kunne kortlægge deres arbejdsprocesser og diskutere disse på tværs af afdelingerne og dermed udveksle viden om organisationen. Skumbrikkerne derimod var 'mediators', der i kraft af deres fysiske kvaliteter var med til at understøtte diskussioner, som ikke kun handlede om kendte aspekter ved arbejdet, men også om ubevidste forhold og aspekter, som var nye eller ukendte for deltagerne, og som bidrog til at udvide deres forståelse, både af organisationen og af arbejdsprocesserne (Stang Våland 2011).

\section{Ejerskab til designet}

Formatet gjorde det altså muligt at materialisere fremtidige indretninger af kontorerne. På den måde var de forskellige workshops med til både at levendegøre og udfordre deltagernes oplevelse af de nye arbejdsrum. Gennem diskussioner over spillepladerne og den fysiske oplevelse af rum 
gennem interaktionen med skumbrikkerne gjorde deltagerne sig bekendt med idéen om den nye arbejdsplads. Medarbejder 1 forklarer, hvordan materialiteterne spillede en rolle:

"Du er nødt til at synliggøre det. Og det var sådan set en meget sjov proces. Jeg synes, det var fint, at den sidste del var med [workshoppen i 1:1-format]. Havde den ikke voeret med, så ville jeg nok have siddet tilbage frustreret. For det var jo dér, vi kom til den virkelige virkelighed. [...] Så fik vi et forslag [tilbage fra designerne], og forhandlede os frem til det endelige [forslag]. Det blev en god proces. [...] Der fik vi indflydelse, og man kan nok ikke undgå, at der sker sådanne ting $i$ processen med, at nogle forudsaetninger laves om, for vi bygger jo ikke rådhus hvert år. Der er nogle ting, man opdager hen ad vejen."

Som sidste del af citatet indikerer, knyttede der sig en særlig udfordring til at arbejde på denne måde. For mange af medarbejderne blev øvelserne i 1:1-workshoppen så virkelighedsnære, at deltagerne begyndte at føle sig som designere. De tog ejerskab til deres idéer og løsningsmodeller og fik konkrete forventninger til, hvor i huset deres afdeling skulle ligge og til afdelingens helt konkrete udformning. For selvom det producerede materiale indgik i den videre proces, var der mange forhold, som blev ændret i det endelige 'layout' for huset som helhed. I et byggeri så komplekst som et rådhus, er det almindeligt, at sådanne ændringer finder sted i løbet af processen. Men for mange af deltagerne skabte dette frustration. De blev irriterede, når det endelige design for afdelingens arbejdsrum blev ændret, så det ikke helt korresponderede med de forslag, som workshoppen havde afstedkommet. Medarbejder 4 fortæller:

"[N]år man først har fået tildelt et areal [gennem 1:1-workshoppen], så varer det $i k k e$ ret lang tid, inden man føler: Det er mit område det her! Og så skal jeg lige pludselig forholde mig til, at jeg [afdelingen] er blevet flyttet hen på et andet areal, som måske arealmoessigt er tilsvarende [...]. Det handler så om, at man skal få noget andet logistik til at gå op [inden for bygningens rammer]. Men nu er jeg altså blevet flyttet, og hvorfor er jeg det?"

Selvom nødvendigheden af disse ændringer blev forsøgt forklaret, var det svært at forstå for medarbejderne. Medarbejder 3 fortæller at:

"det har voeret problematisk at forstå, at når man har lagt skumfiduserne i en eller anden konfiguration, så betyder det ikke nødvendigvis, at så vil man tage et billede af den og så overføre den til en detailindretningsplan".

For nogle gjorde arbejdet med skumbrikkerne det muligt at erfare den konkrete rumlighed (og mangel på afstand) i en sådan grad, at repræsentationen blev til 'virkelighed'. Dette har sandsynligvis påvirket deres forventninger i den forstand, at afvigelsen mellem deres forslag og det færdige design var svær at acceptere. For arkitekterne medførte deltagernes ejerskabsfølelse også udfordringer. Blandt andet fortalte de, at de i arbejdet med at opsamle det omfangsrige materiale, som var produceret i de afdelingsspecifikke 1:1-workshops, havde problemer med at følge med, fordi deltagerne fortsatte med at producere materiale, længe efter workshoppen var slut. Den ene af arkitekterne fortæller:

"Det, der skete efterfølgende, var, at det satte mange tanker i gang hos rigtig mange. Vi havde forestillet os, at [resultatet] var opsamlingen på tankerne, som de skrev ned, så vi havde et materiale at arbejde videre med. 
Men $i$ praksis viste det sig, at det $i$ stedet satte en masse processer i gang, som gjorde, at vi modtog mindst lige så meget materiale efterfølgende på e-mail".

Vores fortælling indikerer, at materialiteter spiller en rolle som katalysatorer for at diskutere arbejdets karakter og det arbejdsrum, arbejdet foregår i. De var desuden med til at illustrere arbejdsrummets rumlighed: størrelse, afstande, omfang, hvilket gav deltagerne en fysisk/rumlig fornemmelse af, hvilken arbejdsplads som var i vente. I tillæg viser fortællingen, at medarbejderne fik oplevelsen af selv at være designere. Gennem omgangen med materialiteterne og i samtalerne om rum fik de ambitioner om det fremtidige arbejde i det fremtidige arbejdsrum. Men når distinktionen mellem deltagernes og designernes rolle, så at sige, bliver uklar, udfordres brugerinddragelsen som ledelsesredskab. Selvom brugerinddragelse i dobbelte designprocesser skaber rum for at håndtere bekymringer og tanker hos medarbejderne i en organisation, er det således også sandsynligt, at den skaber nye forventninger.

\section{Diskussion}

Idéen om den dobbelte designproces illustrerer noget, som designforskere længe har vidst (Cross 2006; Lawson 1997; Heskett 2005), nemlig at designprocesser hverken har en egentlig begyndelse eller et klart slutpunkt. Ligesom livet i organisationer befinder de sig snarere altid 'i midten' (Weick 2004). I designprocesser er der "altid noget som er givet på forhånd, som et tema eller en problematik" (Latour 2009, 4). I vores case var det ikke kun Strukturreformen, men også beslutningen om opførelsen af det nye rådhus, der lå til grund for den komplekse forandringsproces, kommunaldirektøren og hans organisation stod overfor. Hertil kom- mer den særlige udfordring med indførelsen af åbne kontorer og medarbejdernes bekymringer for 'livet' i det nye rådhus. Denne overordnede struktur for huset var besluttet, inden designprocessen gik i gang, og selvom medarbejderne var utilfredse med det, stod det ikke til diskussion. Her benytter kommunaldirektøren brugerinddragelsen som en måde at håndtere medarbejdernes bekymringer på og som en indgang til at igangsætte den organisationsforandring, kommunesammenlægningen fordrede.

På denne baggrund kan man godt indvende, at brugerinddragelsen tjente til at legitimere kommunaldirektørens beslutning om at indføre storrumskontorer. Det var der nogle af medarbejderne, der mente, og man ville også kunne analysere beslutningen som et traditionelt eksempel på kontrol. Men ved blot at affærdige brugerinddragelse som et legitimeringsforsøg, er der fare for, at vi overser, hvad sådanne bestræbelser også kan, fx at give både ledelsen og medarbejderne adgang til ny viden om den daglige arbejdspraksis samt nye ideer til, hvordan arbejdet kan foregå, når de fysiske rammer skifter. I denne artikel har vi derfor taget et andet udgangspunkt, nemlig at undersøge lederens ambition om at involvere medarbejderne i den komplekse og sammensatte proces det er at designe indretningen af et rådhus. Vi har behandlet hans arbejdsform som et eksempel på den 'designtilgang', som idéen om 'ledelse som designarbejde' bygger på (Boland \& Collopy 2004; Yoo m.fl. 2006). I vores case står kommunaldirektøren nemlig over for en opgave, der er så kompleks, at der næppe findes klare og entydige løsninger. I stedet for blot at lade arkitekterne om husets indretning og derefter gennemføre de mange organisatoriske ændringer, som kommunesammenlægningen ville foranledige, søgte kommunaldirektøren i stedet at få tilvejebragt et flertal af løsningsmuligheder, hvor- 
fra der kunne udvikles en samlet løsning, som så igen kunne videreudvikles i takt med, at huset ibrugtages, og den daglige praksis udfoldes. Det er denne måde at arbejde på, vi ovenfor har kaldt for 'bricolage' (Weick 2001; 2004). Hvad der kan betragtes som et godt design, organisatorisk såvel som indretningsmæssigt, er i designtænkningen altså noget, som kun tiden kan vise (Martin 2007). Her er pointen, at de gode løsninger ofte er nogle, vi ikke kender, når processen går i gang. De opstår snarere som muligheder, der får form i selve processen, som i vores case understøttedes af de omfattende brugerinddragelsesaktiviteter.

\section{Design - en netværkseffekt}

Vores studie har fokuseret på et udsnit af brugerinddragelsen, nemlig de workshops, hvor medarbejderne skulle arbejde med indretningen af det nye rådhus. I disse aktiviteter indgik mange forskellige materielle artefakter. Nogle af disse, fx de borde og stole, som medarbejdernes sad på, når de arbejdede med spillepladerne, kan betragtes som tekniske objekter, der ikke blev stillet spørgsmålstegn ved, mens andre - fx de forskellige spilleremedier (spilleplader, tegninger, streger på gulvet, skumbrikker) i et vist omfang fungerede som hhv. grænseobjekter (Star og Griesemer 1989) og epistemiske objekter (Ewenstein og Whyte 2009). Øvelsen med at finde et hensigtsmæssigt 'layout' på tværs af afdelingerne er et eksempel på førstnævnte, idet tegningerne over rådhusets 'layout' var forholdsvis stabile, men alligevel åbne over for flere fortolkninger. I øvelserne i 1:1-format, der vedrørte indretningen af de enkelte afdelinger, fungerede artefakterne snarere som epistemiske objekter, som gennem deres åbenhed og ufuldstændighed udløste spørgsmål, følelser og diskussioner. Fælles for begge typer artefakter er, at de gjorde det muligt for medarbejderne at se deres arbejde og kon- torindretning med 'et andet blik': gennem tegningerne på spillepladerne og gennem omgangen med skumbrikkerne. Artefakterne gav desuden medarbejderne mulighed for udvikle deres egne repræsentationer, som de kunne bruge til at påvirke både hinandens og ledelsens synspunkter. Tilsammen fik øvelserne skabt 'grobund' for udviklingen af flere forslag, selv længe efter at øvelserne var overstået, som en arkitekt beskriver i et af de ovenstående citater.

Sammenfattende kan man sige, at disse artefakter også har fungeret som vigtige involveringsværktøjer eller 'interessement devices' (Akrich m.fl. 2002), der indrullerede medarbejderne i designarbejdet og bidrog til, at deres bekymringer blev oversat til en række forslag til, hvordan arbejdsrummet kunne indrettes. I arbejdet med designet indgik de involverede parter i forskellige netværkskonstellationer på forskellige tidspunkter i projektet: Medarbejderne arbejdede i skiftende grupper og med forskellige artefakter i øvelserne. De forslag, som blev produceret i brugerinddragelsen, kan på den måde betragtes som en netværkseffekt som resultatet af en vis enighed, eller 'alignment', mellem medarbejderne og artefakternes repræsentationer (Callon 1986). Vi har, som sagt, kun kigget på et lille udsnit af det designforløb, der foregik i forbindelse med opførelsen af det nye rådhus, og dermed kun på en lille del af de mange oversættelsesprocesser, som har udspillet sig i den samlede designproces. Valget af løsninger (og delløsninger) kan således betragtes som en række oversættelsesprocesser, hvor de involverede parter indgår i forskellige netværk og mobiliserer andre i kampen for at få deres idéer stabiliseret som designforslag, der kan fortrænge andre forslag.

\section{Designtilgangens udfordringer}

Som 'interessement devices' havde skumbrikkerne en mere medierende rolle end 
spillepladerne. De gjorde en forskel i interaktionen ved at bibringe medarbejderne en rumlig oplevelse, som spillepladerne ikke gav dem. Det var i denne oversættelse, at de forholdsvis faste forestillinger om arbejdspladsens indretning blev etableret (jf. citaterne ovenfor). Det skabte et stærkt ejerskab til resultatet: forestillingen om, hvordan arbejdsrummet skulle organiseres i en endnu ikke-eksisterende bygning. Gennem repræsentationerne får noget, der er virtuelt, altså karakter af at være reelt eller forventeligt. Dette havde som følge, at flere blev skuffede, når deres designidéer blev forkastet, fortrængt af andre forslag eller ændret senere i processen. Disse udviklinger er også led i rækken af de mange oversættelser, som en kompleks designproces består af. For lederen, der indtager en designtilgang, må denne ejerskabets dobbelthed, som på den ene side kan skabe engagement, mere viden og udvidet interesse, og på den anden side skuffelse, når forventningerne ikke indfris, ses som en del af præmissen ved at anvende brugerinddragelse som redskab i 'designtilgangen' (Boland \& Collopy 2004). Brugerinddragelsen er en ramme, gennem hvilken interaktionen med brugerne kan organiseres (Callon 1998), og arkitekterne benytter sig af en lang række værktøjer til at strukturere disse forløb. Men det input, som produceres af brugerne, kan ikke altid holdes inden for rammerne, fordi brugerne naturligt tager 'alt mulig andet' med ind i designarbejdet (erfaringer, idéer osv.), som måske kan føre til en problematisering af rammerne. Af samme grund introduceres der i denne tilgang til 'ledelse som designarbejde' en uforudsigelighed i processen, som skal håndteres.

Man kunne også gøre valget af designløsninger til et spørgsmål om magt, for der er utvivlsomt magt på spil i sådanne processer. Vi mener dog ikke, at arkitekterne og ledelsen nødvendigvis har mere magt end brugerne i denne form for designarbejde. Lederen har en formel opgave $\mathrm{i}$ at træffe en række midlertidige og endelige afgørelser undervejs i processen, men dette er ikke det samme som magtudøvelse i designsammenhænge. Arkitekterne har magt gennem deres professionelle viden, men medarbejderne har en viden om det daglige arbejde, som de øvrige parter ikke har. Vi mener, som Law $(1992,380)$, at det er

"important not to start out assuming whatever we wish to explain. For instance, it is a good idea not to take it for granted that there is a macrosocial system on the one hand, and bits and pieces of derivative microsocial detail on the other. If we do this we close off most of the interesting questions about the origins of power and organization. Instead, we should start with a clean slate. For instance, we might start with interaction and assume that interaction is all that there is. Then we might ask how some kinds of interaction more or less succeed in stabilizing and reproducing themselves: how it is that they overcome resistance and seem to become 'macrosocial'; how is it that they seem to generate the effects such as power, fame, size, scope, or organization with which we are all familiar."

De mange udvekslinger og interaktioner, som denne type designproces består af, er lige så vigtige (hvis ikke vigtigere) for designresultatet som store 'makrosociale' systemer, som fx beslutningen om de åbne kontorlandskaber var et resultat af. Det kunne have været interessant at undersøge, hvordan de mange forskellige idéer, som produceredes i brugerinddragelsen, blev håndteret, diskuteret, forkastet eller forhandlet på plads. Men det ville have stillet nogle metodiske krav til dataindsamlingen, som vi ikke kan imødekomme gennem denne undersøgelse. 


\section{Konklusion}

I denne artikel har vi beskæftiget os med idéen om den dobbelte designproces, hvor udviklingen af organisatorisk design og rumlig indretning tænkes sammen i en gensidig konstituerende proces. Vi har analyseret dette som et eksempel på 'ledelse som designarbejde'. 'Designtilgangen' i casen var baseret på organiseret brugerinddragelse, der tillod medarbejdere på tværs af en kompleks organisation at diskutere og udvikle repræsentationer af deres endnu ikke færdigbyggede arbejdsplads. Analysen har fokuseret på anvendelsen af materielle artefakter i dette designarbejde og på, hvordan forskellige typer af artefakter bragte medarbejderne sammen og mobiliserede dem i en proces, så meninger og idéer om arbejdet kunne udfordres og udvikles. På denne baggrund kan design af organisatoriske forandringer ses som en socio-materiel effekt snarere end alene som en ledelsesbeslutning. Casen viser, at selvom medarbejderne i udgangspunktet var kritiske overfor den overordnede designidé - åbne kontorer med flydende arbejdspladser - og at de forblev kritiske under designprocessen, så har designtilgangen givet dem mulighed for at udvide deres forståelse af egne arbejdsgange og af organisationens funktionsmåde. Tolker man brugerinddragelse som ledelsens forsøg på at legitimere de åbne kontorer, kommer man nemt til at overse de lærings- processer, der også foregår. Hermed ikke sagt, at 'ledelse som designarbejde' ikke er en udfordrende ledelsestilgang. For lederen introducerer det at invitere medarbejdere med ind i disse designprocesser en vis decentralisering af ledelsesopgaven. Dette giver en række muligheder, da medarbejdernes dybe engagement kan bidrage til at skabe forståelse for og fleksibilitet i forhold til en kompleks forandringsproces. Samtidig introducerer det også en grad af uforudsigelighed i ledelsesopgaven, som lederen skal kunne håndtere. For selvom rollefordelingen mellem ledere, brugere og arkitekter var relativ klar i udgangspunktet, og at den rolle, brugerne fik udstukket, 'kun' omfattede produktionen af input til designprocessen, skabte deltagelsen et ejerskab blandt brugerne, som gjorde at både rollefordelingen og opgaven blev uklar. Brugerne fortsætter med at producere input og begynder at optræde som designere, der giver dem ejerskabsfølelser, som samtidig udfordrer ledelsen. Denne udfordring kan måske ses som en svøbe, men er måske netop det, som er designtilgangens mulighed. Den (fortsatte) produktion af idéer, som omgangen med rum og materialiteter skaber, giver lederen mulighed for at få øje på de mange hverdagsting, organisatorisk liv består af. Måske er det netop disse hverdagsting og de relationer, de konstitueres af, som overhovedet gør organisering muligt.

\section{NOTER}

1 Dette kan blandt andet ses i den diskussion om, hvorvidt åbne kontorlandskaber fører til mere videndeling, som har præget den danske debat op igennem nullerne (Bjerrum og Bødker 2003; Hansen 2007; Bakke 2007; Christensen 2009), men også kan spores meget længere tilbage (se fx Oldham og Brass 1979; Hatch 1987; Zahn 1991).
2 Slutbrugerne i et rådhus kan være både borgere, politikere og kommunale medarbejde. I dette projekt var det den sidstnævnte gruppe, som indgik i projektet som slutbrugere, og som var involverede i projektet fra før arkitektkonkurrencen og frem til ibrugtagning af det nye rådhus.

3 Callon (1986) beskriver translationsproces- 
ser som bestående af fire momenter: problematisering (det at skabe en 'sag'), interessement (det at få andre interesserede i ens sag), indrullering (det at tilskrive aktører bestemte roller) og mobilisering (hvor alle nu arbejder for den 'fælles' sag i netværket af allierede).
4 Her taler vi om materialer i bred forstand og ikke kun om de materielle artefakter, der var brugt i forbindelse med brugerinddragelsesaktiviteterne.

5 Analysen i denne artikel bygger primært på materiale fra 10 af disse interviews.

\section{ReferenCER}

Abildgaard, J. S., N. C. M. Nickelsen \& M. Bendixen (2012): Bidrag til et symmetrisk og sociomaterielt arbejdsmiljøperspektiv, i Tidsskrift for Arbejdsliv, 14, 3, 57-75.

Akrich, M., M. Callon \& B. Latour (2002): The key to success in Innovation. Part I: The art of Interessement, i International Journal of Innovation Management, 6, 2, 187-206.

Bakke, J. W. (2007): A Nordic Guide to Workplace Design, Oslo, Nordic Innovation Centre

Bate, P. (2007): Bringing the Design Sciences to Organization Development and Change Management: Introduction to the Special Issue, i Journal of Applied Behavioral Science, $43,1,8-11$.

Bjerrum, E. \& S. Bødker (2003): Knowledge sharing in the 'new office' - possibility or problem?, i P. Dourish \& K. Schmidt (red.): ECSCW 2003: Proceedings of the Eighth European Conference on Computer Supported Cooperative Work, Dordrecht, Kluwer Academic Publishers.

Bjerrum, E., J. Lauring \& A. B. Vangel (2007): Det åbne kontor - en teknologi der fremmer interaktion og videndeling i arbejdet?, i Tidsskrift for Arbejdsliv, 9, 3, 59-71.

Bevan, H. m.fl. (2007): Using a Design Approach to Assist Large-Scale Organizational Change: "10 High Impact Changes" to Improve the National Health Service in England, i The Journal of Applied Behavioral Science, 43, 1, 135-152.

Boland, R. J. \& F. Collopy (red.) (2004): Managing as Designing, Stanford, CA, Stanford Business Books.

Boland, R. J. m.fl. (2008): Managing as Designing: Lessons for Organization Leaders from the Design Practice of Frank O. Gehry, i
Design Issues, 24, 1, 10-25.

Braun, V. \& V. Clarke (2006): Using thematic analysis in psychology, i Qualitative Research in Psychology, 3, 2, 77-101.

Buch, A. (2007): Hvad kan teknologistudier sige arbejdslivsstudier?, i Tidsskrift for Arbejdsliv, 9, 3, 72-87.

Callon, M. (1986): Some elements of a sociology of translation: domestication of the scallops and the fishermen of St Brieuc Bay, i J. Law (red.): Power, action and belief: a new sociology of knowledge?, London, Routledge, 196-223.

Callon, M. (1998): An Essay on Framing and Overflowing: Economic Externalities Revisited by Sociology, i M. Callon (red.): Laws of the Market, Oxford, Blackwell, 244-69.

Chanlat, J.-F. (2006): Space, Organisation and Management Thinking: A Socio-Historical Perspective, i S. Clegg \& M. Kornberger (red.): Space, Organizations and Management Theory, København, Copenhagen Business School Press.

Christensen, P. H. (2009): Rumforskning - fysiske omgivelser i ledelse og organisering af arbejde, København, Jurist og Økonomiforbundets Forlag.

Cross, N. (2006): Designerly Ways of Knowing, Berlin, Springer Verlag.

Ewenstein, B. \& J. Whyte (2007): Visual representations as 'artifacts of knowing', i Building Research and Information, 35, 1, 81-89.

Ewenstein, B. \& J. Whyte (2009): Knowledge Practices in Design: The Role of Visual Representations as `Epistemic Objects', i Organization Studies, 30, 1, 7-30.

Greenwood, R. \& D. Miller (2010): Tackling Design Anew, i Journal of Management Perspectives, 24, 1, 78-88. 
Hansen, H. L. (2007): Spaces for learning and working: A qualitative study of the change of work, management, power and social practices in open offices, Copenhagen Business School (ph.d.-afhandling).

Hatch, M. J. (1987): Physical Barriers, Task Characteristics, and Interaction Activity in Research and Development Firms, i Administrative Science Quarterly, 32, 387-399.

Heskett, J. (2005): Design: A very short introduction, Oxford, Oxford University Press.

Indenrigs- og Sundhedsministeriet (2005): Kommunal Reformen - Kort Fortalt, København, Indenrigs- og Sundhedsministeriet.

Jelinek, M., A. G. L. Romme \& R. J. Boland (2008): Introduction to the special issue: Organization studies as a science for design: creating collaborative artefacts and research, i Organization Studies, 29, 3, 317-329.

Johansson-Skjöldberg, U., J. Woodilla \& M. Cetinkaya (2013): Design Thinking: Past, Present and Possible Futures, i Creativity and Innovation Management, 22,2, 121-146.

Latour, B. (1987): Science in Action, Cambridge, MA, Harvard University Press.

Latour, B. (2005): Reassembling the Social, Oxford, Oxford University Press.

Latour, B. (2009): A cautious Prometheus? A few steps toward a philosophy of design (with special attention to Peter Sloterdijk), i Networks of Design, Proceedings of the Annual International Conference of the Design History Society, UK, University College Falmouth, 3-6 September 2008.

Law, J (1992): Notes on the Theory of the ActorNetwork: Ordering, Strategy, and Heterogeneity, i Systems Practice 5, 4, 379-393.

Lawson, B. (1997): How designers think: the design process demystified, Oxford, UK, Elsevier, Architectural Press.

Martin, R. (2007): Design and Business: Why can't we be friends?, i Journal of Business Strategy, 28, 4, 6-12.

Oldham, G. \& D. Brass (1979): Employee Reactions to an Open-Plan Office: A Naturally Occurring Quasi-Experiment, i Administrative Science Quarterly, 24: 267-284.

Peltonen, T. (2011): Multiple architectures and the production of organizational space in a Finnish university, i Journal of Organizational Change Management, 24, 6, 806-821.

Romme, A. G. L. (2003): Making a difference: Organization as design, i Organizational Science, $14,5,558-573$.

Stang Våland, M. (2010): What we talk about when we talk about space: End User Participation between Processes of Organizational and Architectural Design, Copenhagen Business School (ph.d.-afhandling).

Stang Våland, M. (2011): Between organisation and architecture: end-user participation in design, i International Journal of Work, Organisation and Emotion, 4, 1, 42-60.

Star, S. L. \& J. R. Griesemer (1989): Institutional ecology, 'translations' and boundary objects: Amateurs and professionals in Berkeley's museum of vertebrate zoology 1907-39, i Social Studies of Science, 19,3, 387-420.

Weick, K.E. (2001): Making Sense of the Organization, Oxford, Blackwell.

Weick, K. (2004): Rethinking Organizational Design, i R.J. Boland \& F. Collopy (red.): Managing as Designing, Stanford, CA, Stanford Business Books.

Yoo, Y., R. J. Boland \& K. Lyytinen (2006): From Organization Design to Organization Designing, i Organization Science, 17, 2, 215229.

Zahn, G. L. (1991): Face-to-face communication in an office setting: The effects of distance, structure, and exposure, i Communication Research, 18, 737-754.

Marianne Stang Våland, ph.d., adjunkt, Institut for Organisation, Copenhagen Business School

e-mail:msv.ioa@cbs.dk

Susse Georg, ph.d., professor, Institut for Planlægning, Aalborg Universitet, København e-mail: sgeorg@plan.aau.dk 